\title{
PROBLEMATIKA DAN PERLINDUNGAN HUKUM E-COMMERCE DI INDONESIA
}

\author{
Erie H ariyanto
}

(D osen jurusan Syari'ah STA IN Pamekasan, Jl. Raya Panglegur km. 04 Pamekasan, email: erie.mh@gmail.com)

\begin{abstract}
A bstract:
One of the developments of information technology, telecommunication and computer is appearing the creation of transaction model that is not necessary to meet directly or face to face. The transaction is enough to do by using the electronic media that is internet media. In the transaction of e-commerce, many law problems develop that need a law arrangement briefly and clearly as a guarantee of the law protection for the people involved. This artide tries to answer this problem by giving some alternative solutions in order to make the assurance law in e-commerce transaction formed.
\end{abstract}

\section{Keywords:}

e-commerce, transaksi perdagangan, transaksi

\section{Pendahuluan}

Dewasa ini tidak ada kegiatan manusia modern yang lepas dari teknologi komputer yang dapat membantu dalam menyelesaikan tugas-tugasnya secara cepat dan efisien. Bahkan dalam perkembangannya komputer telah dapat merubah kebiasaan atau gaya hidup yang beralih dari alam wujud atau fisik ke alam elektronik atau non fisik disebut sebagai ruang maya (cyberspace), dimana orang dapat melakukan segala kegiatan melalui internet misalnya memesan barang, memesan tiket pesawat dan sebagainya yang lebih dikenal dengan kegiatan perdagangan elektronik (ecommerce).

Perkembangan komputer tidak lepas pengertian dari komputer yang diberikan oleh para pakar, di antaranya adalah pendapat Robert $\mathrm{H}$. Blissmer yang menekankan pengertian komputer 
ErieH ariyanto

berdasarkan fungsi umum dari komputer. Menurutnya, komputer adalah "suatu alat yang mampu melakukan tugas seperti menerima, memproses input tadi sesuai dengan programnya, dan menyimpan perintah-perintah dan hasil dari pengolahan, menyediakan output dalam bentuk informasi".1

Sedangkan menurut D onald $H$. Sanders, pengertian dari komputer adalah "sistem elektronik untuk memanipulasi data yang cepat dan tepat serta dirancang dan diorganisasi supaya otomatis menerima dan menyimpan data input, memprosesnya dan menghasilkan output dibawah pengawasan suatu langkah-langkah instruksi-instruksi program yang tersimpan di memori (storage program)"2.

Salah satu perkembangan $\mathrm{TI}$, telekomunikasi dan komputer adalah lahirnya model transaksi yang tidak perlu bertemu secara langsung atau face to face. Transaksi cukup dilakukan dengan menggunakan media elektronik yaitu media internet. Transaksi ini dikenal dengan nama elektronik commerce (e-commerce). Dalam bidang perdagangan, internet mulai banyak dimanfaatkan sebagai media aktivitas bisnis terutama karena kontribusinya terhadap efisiensi. Di tengah globalisasi komunikasi yang semakin terpadu (global communication network). Dengan semakin populernya internet seakan telah membuat dunia semakin menciut (shrinking the world) dan semakin memudarkan batas-batas negara berikut kedaulatan dan tatananan masyarakatnya. Komputer sebagai alat bantu manusia dengan didukung perkembangan teknologi informasi telah membantu akses ke dalam jaringan jaringan publik (public network) dalam melakukan pemindahan data dan informasi. 3

E lectronic Commerce atau disingkat e-commerce adalah kegiatankegiatan bisnis yang menyangkut konsumen, manufaktur, service

\footnotetext{
1 Jogiyanto H.M, Pengenalan Komputer, Edisi ke-1, (Yogyakarta: Andi Offset,1989), hlm. 3, dikutip dari Robert H. Blissmer, Computer Annual, An Introduction to Information System 1985-1986, (N ew York: John Wiley \& Sons, 1985), hlm. 1.

2 Donald H Sanders, Computer Today, Second Edition, chapter 1 (New York: Mc. Graw Hill, 1985). hlm. 8

3 Ahmadi Miru, Hukum Kontrak, (Jakarta: Rajawali Pres, 2007), hlm.142. Lihat juga Edmon Makarin, Kompilasi Hukum T elematika. (Jakarta: Raja Grafindo Persada, 2004), hlm. 215 - 251
} 
provider, dan pedagang perantara dengan menggunakan jaringanjaringan komputer. Ada beberapa faktor yang mempengaruhi sistem perdagangan beralih ke media elektronik yaitu pertama ecommerce memiliki kemampuan untuk menjangkau lebih banyak pelanggan dan setiap saat informasinya dapat diakses secara up to date dan terusmenerus; kedua ecommerce dapat mendorong kreativitas dari pihak penjual secara cepat dan tepat dalam pendistribusian informasi yang disampaikan secara periodik; ketiga e-commerce dapat menciptakan efisiensi waktu yang tinggi dan murah serta informatif; dan ecommerce dapat meningkatkan kepuasan pelanggan, dengan pelayanan cepat, mudah, aman, dan akurat

Belum adanya aturan perundangan (hukum positif) yang mengatur transaksi perdagangan dengan model transaksi elektronik (electronic commerce), maka dibatasi pada beberapa aspek hukum dalam perdagangan di Indonesia yaitu dengan menggunakan perspektif hukum perjanjian yang berlaku termasuk juga dari KUHPerdata yang menjadi dasar atau sumber dari perikatan untuk adanya kesepakatan melakukan transaksi perdagangan yang selama ini telah digunakan sebagai dasar dari transaksi perdagangan konvensional.

Mengacu pada 2 prinsip kebebasan sebagai prinsip klasik hukum ekonomi internasional: pertama Freedom of Commerce atau prinsip kebebasan berniaga. Niaga ini diartikan luas dari sekedar kebebasan berdagang (Freedom of Trade). Niaga disini mencakup segala kegiatan yang berkaitan dengan perekonomian dan perdagangan. Jadi setiap negara memiliki kebebasan untuk berdagang dengan pihak atau negara manapun di dunia; kedua Freedom of Communication (kebebasan berkomunikasi, yaitu bahwa setiap negara memiliki kebebasan untuk memasuki wilayah negara Iain, baik melalui darat atau laut untuk melakukan transaksi-transaksi perdagangan internasional. 4

Sistem hukum Indonesia tentang perikatan yang secara mendasar dibedakan menurut sifat perjanjiannya yaitu: Perjanjian Konsensuil -- perjanjian dimana adanya kata sepakat antara para pihak

4 Huala Adolf. Masalah-masalah Hukum Dalam Perdagangan Internasional, Jakarta: Rajawali, 1997), hlm. 26 
ErieH ariyanto

saja, sudah cukup untuk timbulnya perjanjian; Perjanjian Riil-perjanjian yang baru terjadi kalau barang yang menjadi pokok perjanjian telah diserahkan; Perjanjian Formil--adakalanya perjanjian yang konsensuil, adapula yang disyaratkan oleh Undang-undang, di samping sepakat juga penuangan dalam suatu bentuk atau disertai formalitas tertentu. 5

Kegiatan perdagangan adalah masuk dalam aspek hukum perdata dan sumbernya diatur dalam buku III KUHPerdata yaitu tentang perikatan yang secara umum dapat dijelaskan bahwa perdagangan terjadi karena adanya suatu kesepakatan antara para pihak dan kesepakatan tersebut diwujudkan dalam suatu perjanjian dan menjadi dasar perikatan bagi para pihak. Electronic data transmission dalam transaksi elektronik (e-commerce) dapat diantisipasi dengan adanya sistem pengamanan jaringan yang juga menggunakan kriptografi terhadap data dengan menggunakan sistem pengamanan dengan Digital Signature. Digital Signature selain sebagai sistem tekhnologi pengamanan berfungsi pula sebagai suatu prosedur tekhnis untuk melakukan kesepakatan dalam transaksi elektronik atau standart prosedur suatu perjanjian dalam transaksi elektronik, dari proses penawaran hingga kesepakatan kesepakatan yang di buat para pihak. 6

E-commerce merupakan model perjanjian jual-beli dengan karakteristik dan aksentuasi yang berbeda dengan model transaksi jual-beli konvensional, apalagi dengan daya jangkau yang tidak hanya lokal tapi juga bersifat global. Beberapa permasalahan hukum yang muncul dalam bidang hukum dalam aktifitas e-commerce, antara lain: (1) Otentisitas subyek hukum yang membuat transaksi melalui internet; (2) saat perjanjian berlaku dan memiliki kekuatan mengikat secara hukum; (3) Obyek transaksi yang diperjualbelikan; (4) Mekanisme peralihan hak; (5) Hubungan hukum dan pertanggungjawaban para pihak yang terlibat dalam transaksi; (6) Legalitas dokumen catatan elektronik serta tanda tangan digital sebagai alat bukti; (7) Mekanisme penyelesaian sengketa; dan (8)

5 Satrio J, H ukum Perikatan Pada U mumnya, (Bandung: Alumni, 1995), hlm. 45

6 Budi Agus Ruswandi, H ukum dan Internet di Indonesia (Yogyakarta: UII Press 2003), hlm. 129 
Pilihan hukum dan forum peradilan yang berwenang dalam penyelesaian sengketa. ${ }^{7}$

Permasalahan seperti diatas, ternyata telah diatur di Inggris yang didasarkan pada putusan pengadilan dalam perkara In $\mathrm{Re}$ Charge Sevices Limited. Perkara tersebut berisi suatu analisis yuridis mengenai hubungan-hubungan hukum yang tercipta apabila suatu card digunakan untuk melakukan pembayaran. Dalam putusan tersebut, yang merupakan leading case di Inggris, hakim Millet J memutuskan pembayaran dengan charge card/credit card adalah pembayaran mutlak, bukan pembayaran bersyarat kepada pihak merchant.8

Selain itu Millet juga berpendapat, dalam penggunaan kartu, secara serempak bekerja tiga perjanjian yang satu sama lain saling terpisah, yaitu Perjanjian penjualan barang dan/ atau jasa antara pedagang, Perjanjian antara pedagang dan perusahaan penerbit kartu yang berdasarkan perjanjian itu pedagang yang bersangkutan setuju untuk menerima pembayaran yang menggunakan kartu dan Perjanjian antara issuer dengan card holder. ${ }^{9}$

Selama ini penggunaan charge card/credit card di internet, ataupun di berbagai merchant secara offline, seperti di berbagai pusat perbelanjaan memang rawan dari penyalahgunaan. Kerawanan ini terjadi sebab pihak merchant dapat memperoleh nomor kartu kredit beserta masa berlakunya yang tentunya dapat digunakan untuk melakukan transaksi e-commerce.

Ada beberapa permasalahan terhadap konsumen, akibat tidak jelasnya hubungan hukum dalam transaksi ecommerce: pertama Mengenai penggunaan klausul baku, kebanyakan transaksi di cyberspace ini, konsumen tidak memiliki pilihan lain selain hanya meng-click icon yang menandakan persetujuannya atas apa yang dikemukakan produsen di website-nya, tanpa adanya posisi yang cukup fair bagi konsumen untuk menentukan isi klausul; kedua

\footnotetext{
7 Fajar, Mukti. 2007. A spek hukum perjanjian perdagangan dalam transaksi elektronic (electronic commerce) 1. http:/ / digilib.ums.ac.id/ images/ line orange right.gif. (diakses pada tanggal 23 Februari 2009, pukul 10.00 WIB)

${ }^{8}$ N iniek Suparni, Cyberspace Problematika dan Antisipasi Pengaturannya, Jakarta: Sinar Grafika, 2009), hlm. 20

9 lbid., hlm. 21
} 
ErieH ariyanto

Bagaimana penyelesaian sengketa yang timbul. Para pihak dapat saja berada pada yurisdiksi peradilan di negara yang berbeda. Untuk itu, diperlukan pula suatu sistem dan mekanisme penyelesaian sengketa khusus untuk transaksi-transaksi ecommerce yang efektif dan murah; ketiga Hal lainnya adalah masalah keamanan dan kerahasiaan data si konsumen. Hal ini berkaitan juga dengan privasi dari kalangan konsumen.

\section{A spek-aspek Hukum dalam E-Commerce}

E-commerce adalah suatu bentuk bisnis modern melalui sarana internet, karenanya e-commerce dapat dikatakan sebagai perdagangan di internet. Dewasa ini, tampaknya di Negara-negara maju (developed countries), masalah e-commerce ini sudah sangat lumrah dan sudah memiliki perangkat pengaturan hukumnya. Adapun di Indonesia ecommerce masih relatif baru dan belum menyentuh keseluruh lapisan masyarakat, melainkan hanya pada golongan atau kelompok terbatas. Lebih dari itu, di Indonesia belum memiliki perangkat hukum khusus, bahkan belum memiliki visi dan strategi nasional.

Dalam praktik pemakaian dan pemanfaatan teknologi atau jaringan internet melalui bisnis e-commerce memiliki jaringan luas dan mendunia, sehingga dengan mudah orang dapat mengakses setiap saat tanpa adanya kontak fisik antara user/konsumer, pembeli pelanggan dengan penjual. Data mengenai barang produksi beserta penjelasan tentang kualitas dan kuantitasnya sudah tersedia, bahkan pembayaran langsung (purchasing) via kartu kredit dapat langsung dilaksanakan melalui jaringan net tersebut setelah segala yang berkaitan dengan transaksi itu jelas dan diterima.10

Budaya internet sebagai tanda-tanda kemajuan dunia begitu mempesona masyarakat dunia, ia telah menawarkan keuntungan secara ekonomis, finansial, tenaga, dan lain lain dalam perkembangan dunia komunikasi dan informasi, baik domestik maupun internasional. Meskipun demikian, dibalik keuntungan-keuntungan komunikasi bisnis via internet ini, terdapat problematika hukum yang menarik untuk dikaji karena dalam bisnis via internet ini, para pihak baik itu produsen ataupun konsumen, penjual ataupun pembeli, baik

10 lbid., hlm. 32 
dalam fase kontak bincang-bincang (pre contractuale fase) atau lainnya sama sekali tidak bertemu fisik, melainkan hanya hubungan melalui e-mail dan lainnya.

Dengan modus seperti ini, perlu adanya tatanan hukum yang mengatur, perlu adanya perlindungan hukum (Rechtsbesecherming) bagi para pihak yang mengadakan perjanjian (kontrak). Di Negaranegara barat seperti Amerika dan Inggris atau Uni Eropa serta beberapa negara ASEA N, seperti Singapura dan Thailand, perangkat hukum seperti di atas sudah ada. Maka Indonesia, sepertinya harus pula berupaya keras mengejar ketertinggalan ini, dengan mendasarkan diri kepada permasalahan-permasalahan hukum yang ada dalam konteks sistem hukum Indonesia.

Dengan menggunakan jaringan internet, tidak hanya sekedar data atau informasi tertulis saja yang dapat diperoleh dan dipertukarkan, tetapi juga suara dan gambar. Dalam kaitan ini internet sudah merupakan Integrated Services Digital N etwork (ISDN). Oleh karena itu, tidaklah mengherankan apabila dunia internet disebut sebagai virtual world, yang sering diterjemahkan kedalam bahasa Indonesia dengan istilah"dunia maya", yang dilawankan dengan real world atau "dunia nyata", yaitu dunia fisik tempat kita hidup. ${ }^{11}$

Dunia maya ini telah mengubah kebiasaan banyak orang, yaitu orang-orang yang dalam kehidupannya terbiasa menggunakan internet. Berbelanja, mengirim surat, mengirim surat lamaran kerja, berkirim foto, mencari informasi, melakukan pembicaraan jarak jauh tidak ubahnya seperti sedang bertelepon, mengambil uang dari bank, membuat desain bangunan oleh arsitek, berkonsultasi tatap muka (yaitu masing-masing pihak muncul gambarnya pada layar komputer mereka, karena setiap computer dilengkapi dengan kamera), melihat film, mendengarkan lagu-lagu Compact $D$ isc, mendengarkan radio, dan lain lainnya. Semua ini dapat mereka lakukan melalui internet. Praktis pada saat ini pada hamper semua kegiatan yang dapat dilakukan di dunia nyata (real world) dapat dilakukan di dunia maya (virtual world). Bahkan di dunia maya orang telah melakukan berbagai tindakan kejahatan yang justru tidak dapat dilakukan di dunia nyata.

11 lbid., hlm. 34 
ErieH ariyanto

Karim Benyekhlef berpendapat, bahwa seseorang tidak dapat dikatakan sudah memahami betul fenomena mengenai dunia maya, apabila pemahamannya hanya terbatas pada unsur-unsur tehnik saja dan belum menyadari tentang masalah-masalah hukum dari dunia maya itu. Berbelanja atau melakukan transaksi di dunia maya melalui internet sangat berbeda dengan berbelanja atau melakukan transaksi di dunia nyata. Kenyataan ini telah menimbulkan keragu-raguan mengenai hukum dan yurisdiksi hukum yang mengikat para pihak yang melakukan transaksi tersebut. Ada sementara pihak yang berpendapat, bahwa karena transaksi tersebut terjadi di dunia maya hukum yang berlaku di dunia nyata tidak berlaku. Pendapat ini menjadi kuat karena pada kenyataannya tidak ada pemilik tunggal dari internet. 12

Sejalan dengan apa yang telah dikemukakan diatas, terdapat kebingungan mengenai, apakah hukum perdata dan hukum pidana yang berlaku di dunia nyata berlaku bagi internet. Banyak pengguna internet yang memiliki pandangan bahwa dunia internet tidak mempunyai/ memiliki hukum, dan sebaiknya pemerintah tidak boleh mencampuri dan memasuki dunia internet.

Pendapat seperti ini sebenarnya tidak sepenuhnya benar, karena dunia maya di mana transaksi-transaksi ecommerce berlangsung adalah memang dunia yang lain dari dunia nyata tempat kita sesungguhnya hidup. Tempat di mana kita bernafas, dan merasakan kenikmatan dan kesakitan jasmaniah adalah di dunia nyata bukannya di dunia maya. Akan tetapi, di dunia maya tempat manusia dapat berinteraksi di antara sesamanya dan dapat melakukan berbagai perbuatan hukum, tidak mustahil manusia melakukan perbuatan-perbuatan hukum yang melanggar hak hukum dari orang lain. Oleh karena itu, di dunia maya perlu ada hukum dan perlu pula hukum tersebut dapat ditegakkan apabila dilanggar. Tanpa adanya hukum di dunia maya dan tanpa dapat ditegakkannya hukum itu apabila dilanggar, sudah barang tentu akan menimbulkan keadaan yang kacau, persis apabila hal itu terjadi di dunia nyata. ${ }^{13}$

12 Ibid., hlm. 32

13 Ibid., hlm. 36 
Semua perbuatan hukum yang dilakukan di dalam dunia maya,adalah perbuatan-perbuatan hukum yang dilakukan oleh manusia-manusia yang berada di dunia nyata. Hanya perbuatan tersebut dilakukan menggunakan media atau sarana internet, Jasmani manusia yang melakukan perbuatan tersebut tidak berada dan hidup di dunia maya. Mungkin kelak teknologi akan benar-benar dapat menciptakan makhluk-makhluk nyata, yaitu manusia maya dan binatang maya, sebagaimana yang sering kita lihat di film-film, dan manusia maya ini yang nantinya melakukan sendiri perbuatanperbuatan hukum itu tanpa perintah dan kendali manusia yang berada di dunia maya.

Akankah mungkin terjadi hal yang demikian itu? Bagi kita yang hidup di dunia nyata, apabila memang telah muncul manusiamanusia maya yang seperti itu, kita tidak akan menganggap perlu dalam dunia maya terdapat hukum dan penegakannya apabila dilanggar sepanjang perbuatan hukum itu tidak menjangkau atau memberikan dampak yang merugikan bagi manusia di dunia nyata. Interaksi dan perbuatan hukum yang terjadi melalui atau di dunia maya adalah sesungguhnya interaksi antara sesame manusia di dunia nyata, dan apabila terjadi pelanggaran hak atas perbuatan hukum yang dilakukan oleh manusia dari dunia nyata dan hak yang dilanggar adalah hak dari manusia dari dunia nyata, maka hukum yang berlaku dan harus diterapkan adalah hukum dari dunia nyata.

A kses kita kepada internet dapat diakhiri seketika oleh access provider yang bersangkutan apabila kita melanggar syarat-syarat perjanjian. Di samping syarat-syarat perjanjian tersebut, terdapat pula ketentuan-ketentuan yang menyangkut sopan santun berkomunikasi melalui internet yang disebut N etiquette, yaitu code of conduct dari internet. Aturan-aturan $\mathrm{N}$ etiquette dipatuhi secara sukarela oleh kebanyakan pengguna internet, karena mereka telah memahami dan menyetujui bahwa mereka memfasilitasi penggunaan yang efisien dari jasa-jasa internet dan memimimalkan kesulitan yang timbul dari penyalahgunaan internet.14

$N$ etiquette telah menjadi penting terutama sejak hukum yang tradisional belum disesuaikan terhadap masalah-masalah baru yang

${ }^{14}$ Makarin, Kompilasi H ukum T elematika, hlm. 25 
ErieH ariyanto

timbul berkaitan dengan internet dan jasa-jasa internet yang baru. Internet Service Provider (ISP) dapat pula menghentikan akses kita pada internet apabila kita melanggar $\mathrm{N}$ etiquette, seperti mengirimkan banyak sekali surat atau brosur yang merupakan junk e-mail kemanamana. Dalam praktiknya, adalah biasa dilakukan oleh pihak yang merasa terganggu untuk langsung menghubungi internet service provider dari seseorang yang telah mengganggunya, dan meminta agar ISP tersebut memutuskan hubungan si pengganggu apabila gangguan-gangguan tersebut itu terjadi.

Pada transaksi-transaksi yang tradisional, segala sesuatunya dilaksanakan dengan menggunakan dokumen kertas. Dengan kata lain, transaksi-transaksi tersebut merupakan paper-based transaction. A pabila terjadi sengketa di antara para pihak yang bertransaksi, maka dokumen-dokumen kertas itulah yang akan diajukan sebagai bukti oleh masing-masing pihak untuk memperkuat posisi hukum masingmasing. Hal ini berbeda sekali dengan transaksi E-commerce. Transaksi E-commerce adalah paperless transaction. Dokumen-dokumen yang dipakai bukanlah paper document, tetapi digital document.15

Sumber atau otentifikasi dari bukti yang diterima oleh suatu sistem telematik dari sitem telematik yang lain, tidak dapat dipastikan. Dengan kata lain, sulit dipastikan mengenai otentifikasinya. Metode pengaman dengan menerapkan cryptography system bermaksud menjawab masalah tersebut. Namun, perlu disadari mengenai sampai sejauh mana undang-undang Indonesia telah mengakomodasi aspek-aspek hukum dari cryptography system tersebut. A pakah pengadilan Indonesia dapat menerima data atau informasi yang disampaikan dalam hard disk computer atau dalam disc (cakram), dan optic diskette (disket optik) dapat diakui sebagai alat bukti yang kuat? Sampai sejauh ini Indonesia belum memiliki hukum tentang Internet (atau hukum tentang E-commerce).

15 Seperti telah dikemukakan oleh Toh See Kiat dalam bukunya Law of T elematic D ata Interchange, bahwa sampai bukti tersebut di-print-out di dalam hard copy, bukti dari suatu computer mudah sekali menghilang, mudah diubah tanpa dapat dilacak kembali, tidak berwujud, dan sulit dibaca. 


\section{H ubungan H ukum Para Pihak dalam E-commerce}

Hukum harus dapat menegaskan secara pasti hubunganhubungan hukum dari para pihak yang melakukan transaksi ecommerce. Dalam kaitan ini, hukum Indonesia belum mengaturnya. dibawah ini akan diberikan contoh, yaitu dalam hal e-commerce yang dilaksanakan dengan menggunakan change card atau credit card sebagai alat pembayaran. Misalnya bank yang menjadi penerbit kartu (card issuer) dari suatu change card atau credit card diharapkan pada suatu kasus di mana pemegang kartu (card Holder) menolak bertanggung jawab atas pelaksanaan pembayaran atas beban change card atau credit card miliknya dengan alasan barang yang dibeli mengandung cacat. Kasus ini menimbulkan suatu masalah hukum mengenai: apakah pembayaran yang dilakukan dengan suatu change atau credit card merupakan pembayaran mutlak, ataukah hanya pembayaran bersyarat kepada penjual barang. Jelas peraturan perundang-undangan Indonesia belum mengatur hal tersebut.16

Di Inggris hal ini sudah diatur, yaitu berdasarkan putusan pengadilan dalam perkara In Re Change Services Limited (1986). Perkara tersebut berisikan suatu analisis yuridis mengenai hubunganhubungan hukum yang tercipta apabila suatu card digunakan untuk melakukan pembayaran. Dalam putusan ini, yang merupakan leading case di Inggris, Millet J., yaitu hakim yang memeriksa perkara ini memutuskan bahwa payment by a change card or a credit card was an absolute and not a conditional payment to the retaile. Dari putusan pengadilan tersebut dapat diketahui bahwa menurut hukum inggris, pembayaran yang dilakukan oleh suatu change card atau credit card merupakan pembayaran mutlak dan bukan merupakan pembayaran bersyarat kepada penjual barang.

Selain asas yang telah dikemukakan di atas, Miller J., telah meletakkan pula asas lain dengan mengemukan pendapatnya bahwa pada pengguna kartu, secara serentak bekerja 3 (tiga) perjanjian yang satu sama lain saling terpisah, yaitu sebagai berikut,

16 Esther Dwi Magfirah, Perlindungan Konsumen Dalam ecommerce, (Yogyakarta: Fakultas IImu Hukum Univesitas Gajah Mada, 2004), hIm. 130 
ErieH ariyanto

a. Perjanjian penjualan barang dan/ jasa antara pedagang dan pemegang kartu;

b. Perjanjian antara pedagang dan perusahaan penerbit kartu, yang berdasarkan perjanjian itu pedagang yang bersangkutan setuju untuk menerima pembayaran yang menggunakan kartu itu;

c. Perjanjian antara perusahaan penerbit kartu dan pemegang kartu, atau pemegang rekening, yang berdasarkan perjanjian itu pemegang kartu menyetujui untuk melunasi pembayaran yang telah dilakukan oleh penerbit kartu kepada penjual barang dan/ jasa berkenaan dengan penggunaan kartu oleh pemegang kartu yang bersangkutan. ${ }^{17}$

\section{Pembatasan Tanggung Jawab Para Pihak}

Dalam perjanjian transaksi e-commerce sebaiknya dipikirkan untuk dimuat klausul mengenai pembatasan tanggung jawab dari para pihak. Pembatasan tanggung jawab dari para pihak ini sangat penting, agar supaya jelas dari para pihak akan batas-batas dari tanggung jawab masing-masing pihak. Namun yang sangat penting untuk diperhatikan, ialah misalnya berupa klausul-klausul eksemsi (exemption clause atau disclaimer), melanggar asas kepatuhan yang berlaku pada hukum yang dipilih oleh para pihak untuk diterapkan dalam menyelesaikan sengketa diantara mereka.

Pembatasan tanggung jawab tersebut dapat pula menentukan batas jumlah ganti kerugian yang harus di bayar oleh pihak yang satu kepada pihak yang lainnya, apabila timbul sengketa. Dengan demikian, para pihak sudah sejak dini berapa besar kemungkinan masing-masing pihak harus menanggung kewajiban pembayaran ganti kerugian apabila pihaknya cidera janji, dan kemudian diputuskan oleh pengadilan untuk membayar sejumlah ganti kerugian kepada pihak penggugat.18

a. Pilihan Hukum (choice of law)

Sekali seseorang mendirikan suatu perusahaan dan berusaha secara elektronik, maka perusahaan dan usaha itu tidak

17 Suparni, Cyberspace, hlm. 48

18 Makarin. Edmon, Kompilasi Hukum Telematika, (Jakarta: Raja Grafindo Persada, 2004) hlm. 34 
berlangsung hanya sebatas negara di mana perusahaan itu didirikan. Perusahaan akan melakukan usaha-usahanya melewati semua batas negara yang ada di dunia ini. Oleh karena itu, hubungan-hubungan hukum yang terjadi karena transaksi ecommerce bukan saja akan merupakan hubungan keperdataan nasional yang tunduk pada hukum perdata dari suatu negara tertentu, dalam hal indonesia tunduk pada Kitab-Kitab UndangUndang Hukum Perdata Indonesia, tetapi merupakan hubungan keperdataan internasional yang termasuk dalam ruang lingkup Hukum Perdata Internasional.

A pabila timbul suatu perselisahan yang menyangkut suatu transaksi ecommerce di antara orang atau badan-badan hukum yang berkedudukan di Indonesia dan transaksi tersebut berlangsung di Indonesia, sedangkan untuk transaksi tersebut para pihak sebelumnya tidak membuat perjanjian diantara mereka maka masih mudah bagi hakim untuk menentukan atau bagi para pihak untuk melakukan kesepakatan di kemudian hari setelah timbulnya perselisihan itu, agar perselisihan itu, agar perselisihan tersebut diselesaikan menurut hukum indonesia.19

Namun bagaimanakah halnya apabila transaksi ecommerce tersebut berlangsung diantara pihak-pihak yang merupakan penduduk dua negara yang berbeda? Sebagai contoh, toko buku Gramedia di jakarta memesan buku dari Amazon.com di Amerika Serikat melalui internet, ternyata kemudian buku-buku tersebut sangat terlambat, atau dikirim dengan salah alamat, yaitu misalnya menyimpang ke alamat lain, bahkan ke alamat lainnya tersebut ada di negara lain, misalnya ke Kuala Lumpur-Malaysia. Ke pengadilan manakah pihak Gramedia akan melakukan gugatannya? Ke pengadilan Indonesia ataukah ke pengadilan Amerika Serikat? Hukum manakah yang harus diberikan oleh hakim, apakah hukum Indonesia ataukah hukum A merika?

A pabila yang diberlakukan adalah hukum dari negara di mana perbuatan itu dilakukan, akan sulit sekali untuk menentukan di negara mana perbuatan itu dilakukan. A pakah perbuatan itu dilakukan di Indonesia atau di Amerika Serikat.

19 Ibid., hlm. 34 
ErieH ariyanto

Mengingat transaksi itu terjadi di dunia maya (virtual world atau cyberspace) yang tidak mengenal batas negara, maka akan sulit menentukan di negara mana peristiwa hukum tersebut terjadi. Karena transaksi tersebut terjadinya di dunia maya, maka transaksi tersebut tidak dapat dikatakan terjadi di Amerika Serikat atau terjadi di Indonesia. Transaksi itu tidak terjadi di negara manapun juga, tetapi terjadinya di "antah berantah".

Apakah seyogianya hukum yang berlaku ditentukan berdasarkan hukum dari negara tergugat, ataukah berdasarkan hukum negara dari penggugat? Atau apakah seyogianya didasarkan kepada hukum negara dari pembeli? Pertanyaanpertanyaan ini merupakan masalah-masalah yang terletak dalam bidang Hukum Perdata Internasional.

Masalah-masalah diatas akan dapat dipecahkan apabila antara pembeli, dalam hal kasus diatas adalah toko buku Gramedia dan penjual, dalam hal kasus diatas adalah Amazon.com, dibuatkan suatu perjanjian yang di dalamnya dimuat suatu klausul yang menentukan hukum dari negara mana yang akan diberlakukan apabila timbul perselisihan di antara mereka kelak. Namun, pada pemesanan barang yang dilakukan oleh konsumen perorangan (bukan pedagang) kepada penjual, biasanya pemesanan itu tidak berdasarkan perjanjian. Dalam hal tidak adanya suatu perjanjian, maka masalah-masalah diatas pasti akan muncul.

b. Yurisdiksi Pengadilan (choice of forum)

Kesulitan kesulitan yang timbul apabila terjadi sengketa antara para pihak di dalam transaksi e-commerce, bukan saja menyangkut pilihan hukum yang akan diterapkan untuk dijadikan dasar menyelesaikan sengketa yang timbul, akan tetapi juga mengenai pilihan pengadilan yang akan memeriksa sengketa tersebut. Hal ini dapat dihindari apabila para pihak menentukan di dalam perjanjian diantara mereka, pengadilan mana yang mereka pilih untuk menyelesaikan sengketa yang mungkin timbul masalah dikemudian hari, berkenaan dengan pelaksanaan dan penafsiran perjanjian diantara mereka. 
Para pihak dapat pula menentukan di dalam perjanjian tersebut, bahwa sengketa yang mungkin timbul kelak di kemudian hari diselesaikan oleh suatu badan arbitrase, baik arbitrase institusional maupun arbitrase ad hoc. Klausul dalam perjanjian yang mengatur mengenai hal ini disebut arbitration provision atau klausul arbitrase.

\section{Perlindungan Hukum bagi Konsumen}

Di Indonesia, perlindungan hak-hak konsumen dalam ecommerce masih rentan. Undang-undang. Perlindungan konsumen yang berlaku sejak tahun 2000 memang telah mengatur hak dan kewajiban bagi produsen dan konsumen, namun kurang tepat untuk diterapkan dalam e-commerce. Untuk itu perlu dibuat peraturan hukum mengenai cyberlaw termasuk didalamnya tentang e-commerce agar hak-hak konsumen sebagai pengguna internet khususnya dalam melakukan transaksi e-commerce dapat terjamin.

Masalah hukum yang menyangkut perlindungan konsumen semakin mendesak dalam hal seorang konsumen melakukan transaksi ecommerce dengan merchant di Negara lain. Pada jual beli jarak jauh seperti itu, kecurangan seringkali terjadi dan dengan demikian konsumen harus dilindungi.20 Kecurangan-kecurangan tersebut dapat terjadi yang menyangkut keberadaan penjual, menyangkut barang yang dibeli, dan menyangkut purchase order serta pembayaran oleh pembeli.21

Kecurangan yang menyangkut keberadaan penjual, misalnya bahwa penjualan, yaitu virtual store yang bersangkutan, merupakan toko yang fiktif. Yang menyangkut barang yang dikirim oleh penjual, misalnya bahwa barang tersebut tidak dikirim kepada pembeli, atau terjadi kelambatan pengiriman yang berkepanjangan, terjadinya kerusakan atas barang yang dikirim atau barang yang dikirimkan tersebut cacat, dan lain-lain. A dapun yang menyangkut purchase order dan pembayaran oleh pembeli disangkal oleh penjual kebenarannya.

20 Madkaay, Ejan., Daniel Poulin and Piere Tudel, The electronic Superhigtway: The Shape of Technologi and The Law Come The Hague (London: kluwer Law International :1995), hlm. 105

21 Magfirah, Perlindungan Konsumen, hlm. 67 
ErieH ariyanto

Misalnya penjual hanya mengakui bahwa jumlah barang yang dipesan kurang dari yang tercantum didalam purchase order yang dikirimkan secara electronic dan/harga per unit dari barang yang dipesan oleh pembeli dikatakan lebih tinggi daripada harga yang dicantumkan di dalam purchase order .

Dalam kaitan ini, undang-undang harus dapat memberikan perlindungan hukum kepada konsumen yang beriktikad baik, seperti perlindungan yang diberikan kepada konsumen yang melakukan jual beli di dunia nyata. Mengingat Indonesia belum mempunyai undang-undang tentang e-commerce, dan Undang-Undang No 8 Tahun 1999 tentang perlindungan konsumen tidak didasarkan pada telah adanya undang-undang tentang ecommerce atau undangundang tentang internet yang berlaku di Indonesia, maka UndangUndang No 8 Tahun 1999 tentang Perlindungan Konsumen itu belum menyinggung pengaturan mengenai perlindungan konsumen dalam transaksi e-commerce melalui internet.

\section{Penutup}

E-commerce telah memenuhi syarat sahnya perjanjian (1320 KUH Perdata), namun masih ada celah hukum yakni pada syarat "kesepakatan" rentan adanya unsur penipuan dan "kecakapan" ini sulit diketahui, dan untuk pembuktiannya menggunakan alat bukti berupa "print out" dengan mendasarkan pada 1866 KUH Perdata, 164 HIR jo pasal 15 UU N0.8/ 1997 tentang Dokumen Perusahaan

Sebelum Cyberlaw terwujud, maka peraturan perundangan lain yang terkait dengan internet / e-commerce dapat digunakan untuk mengantisipasi persoalan-persoalan hukum yang timbul. Ada beberapa peraturan perundangan yang terkait antara lain: 1) UU larangan praktek monopoli dan persaingan usaha tidak sehat No.5/ 1999 UU, 2) Perlindungan Konsumen No. 8/ 1999, 3) UU Telekomunikasi No. 36/ 1999, 4) UU Hak Cipta No.12/ 1997, 5) UU Merek No. 15/ 2001, 6) UU Dokumen Perusahaan No. 8/ 1997 (pasal 15) jo Peraturan Pemerintah No.88/ 1999 tentang Tata Cara Pengalihan Dokumen Perusahaan, SEMA No.39/TU/ 88/ 102/ Pid, dan 7) UU Pemanfaatan Tekhnologi Informasi (UU PTI).

Kehadiran TI yang berupa internet membuat sektor perdagangan di dalam dan di luar negeri semakin maju pesat. $\mathrm{Hal}$ ini 
dibuktikan dengan kehadiran transaksi e-commmerce dan akan memperlancar sistem produktifitas dan pendistribusian barang / jasa dalam memenuhi berbagai kebutuhan konsumen. Dalam transaksi ecommerce ini banyak permasalahan hukum yang berkembang, sehingga pengaturan hukum yang jelas dan tegas terhadap masalah transaksi e-commerce sangat dibutuhkan sebagai jaminan perlindungan hukum bagi para pihak. Harapan yang dikehendaki, dengan pengaturan hukum maka pemanfaatan TI akan semakin optimal, terutama untuk kebutuhan transakasi e-commerce itu sendiri.

\section{D aftar Pustaka}

Ahmadi Miru, Hukum Kontrak dan Perancangan Kontrak, Jakarta: Rajawali Pres, 2007

Donald $\mathrm{H}$ sanders, Computer Today, Second Edition, New York: Mc. Graw Hill, 1985

Fajar, Mukti. 2007. A spek hukum perjanjian perdagangan dalam transaksi elektronic (electronic commerce) 1. http:/ / digilib.ums.ac.id/ images/ line orange right.gif. (diakses pada tanggal 23 Februari 2009, pukul 10.00 WIB)

Huala A dolf. M asalah-masalah H ukum D alam Perdagangan Internasional, Jakarta: Rajawali, 1997

Jogiyanto H.M, Pengenalan Komputer, Edisi ke-1, Cetakan ke-1, Yogyakarta: Andi Offset, 1989

Kadir, Abdul dan Triwahyuni, Terra. Pengenalan Teknologi Informasi. Yogyakarta: Andi Offset, 2005.

Mackaay, Ejan., Daniel Poulin and Piere Tudel, The electronic Superhigtway: The Shape of Technologi and The Law Come The H ague, London: Kluwer Law International, 1995 
ErieH ariyanto

Magfirah, Esther Dwi. Perlindungan Konsumen Dalam E-commerce, Yogyakarta: Fakultas IImu Hukum Univesitas Gajah Mada, 2004.

Makarin, Edmon. Kompilasi Hukum Telematika. Jakarta: PT. Raja Grafindo Persada, 2004

Niniek suparni, Cyberspace Problematika dan A ntisipasi P engaturannya, Jakarta: Sinar Grafika, 2009

Riswandi, Budi Agus. Hukum dan internet di Indonesia. Yogyakarta: Universitas Islam Indonesia Pres, 2003.

Robert $\mathrm{H}$. Blissmer, Computer Annual, An Introduction to Information System 1985-1986, New York: John Wiley \& Sons, 1985

Satrio J, H ukum Perikatan Pada U mumnya, Bandung: Alumni, 1995. 